\title{
Reliance on Supplemental Nutrition Assistance Program Continued to Rise Post-Recession
}

$\mathrm{T}$ Though the Great Recession officially ended in June $2009,{ }^{1}$ the effects of a weak economy continue to ripple through the nation. High unemployment and poverty persist, ${ }^{2}$ and in 2010, nearly one in four Americans struggled to afford sufficient food. ${ }^{3}$ Amidst this enduring economic backdrop, participation in the Supplemental Nutrition Assistance Program, or SNAP (formerly known as food stamps), continued to rise. This brief uses data from the 2007, 2009, and 2010 American Community Survey to provide an up-to-date look at changes in SNAP receipt over the course of the recession, with particular attention to differences in receipt by place type (rural, suburban, central city locations) and family structure. ${ }^{4}$

\section{Increases During the Recession}

In December 2010, 44 million people received SNAP benefits. ${ }^{5}$ This compares with 27.3 million in November 2007 (one month pre-recession) and 35.9 million in July 2009 (one month post-recession). ${ }^{6}$ As might be expected, SNAP receipt increased in all place types both during the 2007-2010 and 2009-2010 periods (see Figure 1), rising 4.2 percentage points since 2007 and 1.6 percentage points since 2009. Receipt was highest in rural areas until 2010, when central city residents caught up through a large increase in receipt (2.1 percentage points between 2009 and 2010). Suburban rates remain substantially lower than in other place types both pre- and post-recession.

Figure 1. Percent of Households Reporting SNAP Receipt, by Place Type
Rural

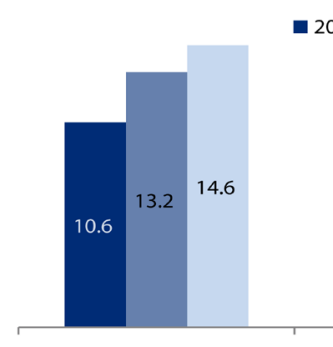

$2007-2009-2010$

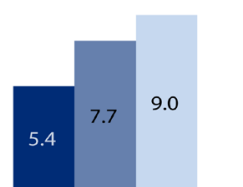

Suburban

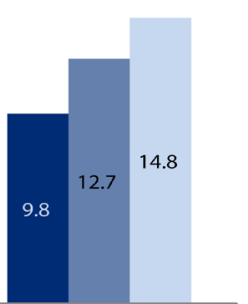

Central City
Source: 2007, 2009, \& 2010 American Community Survey

\section{Key Findings}

- Receipt of SNAP continued to rise in 2010, increasing 4 percentage points since the recession began in 2007, and 1.6 percentage points since 2009 .

- By 2010, nearly 12 percent of households reported receiving SNAP benefits. Receipt is even higher in rural places and central cities, approaching 15 percent in both places.

- $\quad$ Reliance on SNAP was still very high among single parents in 2010, rising 10 percentage points nationally since the recession began. In 2010, 42 percent of single mothers relied on SNAP; in rural places, the rate is as high as one in two.

\section{Critical Support for Families in Need}

Households that received SNAP benefits in 2010 had a median household income of $\$ 17,912$, compared with the national median of $\$ 50,046 .^{7}$ This is despite the fact that 76 percent of families receiving SNAP had at least one employed member. ${ }^{8}$ According to the U.S. Food and Nutrition Service, the average household's monthly benefit was just \$289.61 in 2010, ${ }^{9}$ totaling $\$ 3,475.32$ per year. As such, it is no surprise that over one-third of the households that received SNAP still reported food insecurity. ${ }^{10}$ Although SNAP access is widespread, ${ }^{11}$ it is clear that the program alone does not reach all those in need and that imposing stricter limits on SNAP allocations may move more households into food insecurity.

Receipt of benefits is even more widespread among certain groups in need, suggesting that SNAP does reasonably well reaching its target populations. For example, more than one in five households with a disabled member relied on SNAP in 2010 (21.4 percent), with estimates reaching 38.1 percent in some places. ${ }^{12}$ In addition, while 11.9 percent of households 
Table 1. Households with Children Receiving SNAP in last 12 Months, by Family Type (2010)

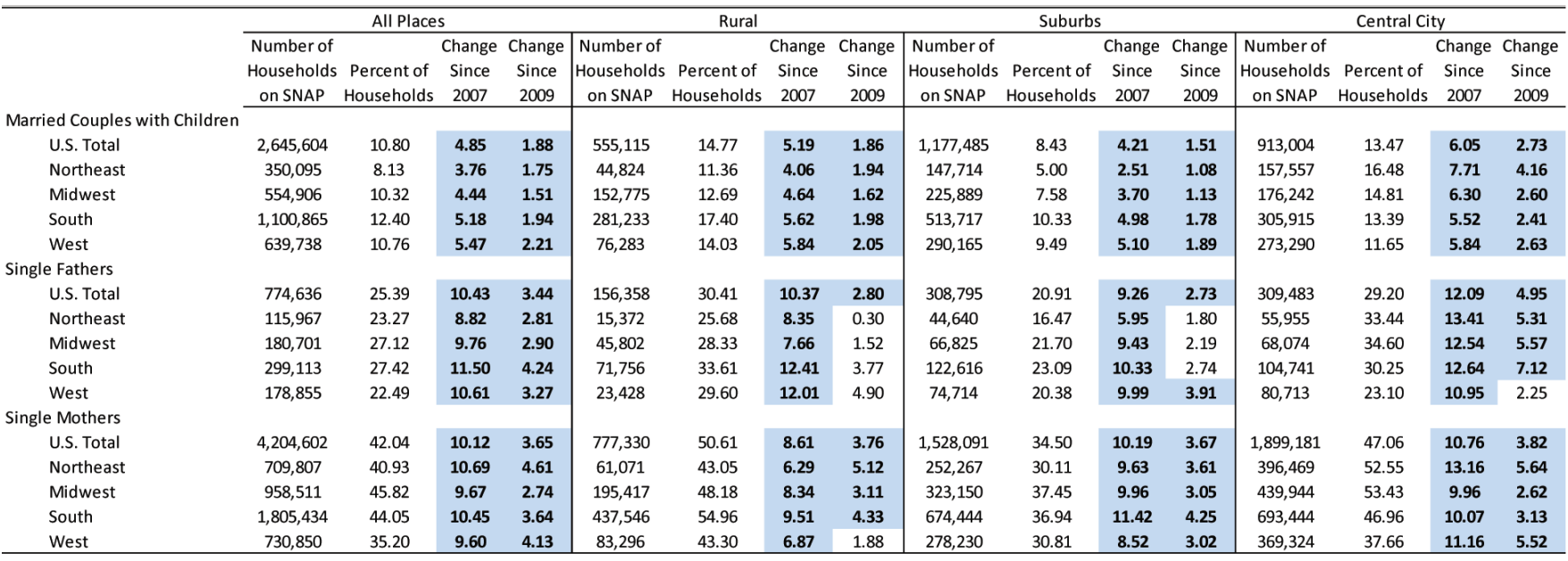

Note: Bold and shaded typeface indicates statistically significant change ( $p<0.05)$. Includes ONLY families with children. Change columns indicate percentage point changes.

Source: 2007, 2009, \& 2010 American Community Survey

received SNAP benefits in 2010, receipt was as high as 20.4 percent among households with children. ${ }^{13}$ In addition, SNAP use increased disproportionately among these populations during the recession. For example, while overall SNAP receipt increased 4.2 percentage points between 2007 and 2010, the increase among families living below the federal poverty line was 7.7 percentage points; by $2010,44.3$ percent of these families received SNAP. ${ }^{14}$ Among households with a disabled member, receipt increased by 5.9 percentage points during the recession. ${ }^{15}$ Perhaps the most dramatic increases, though, came among single parents (see Table 1). Among both single mothers and fathers, SNAP receipt increased by more than 10 percentage points since the beginning of the recession and by more than three percentage points since 2009. By 2010, more than 25 percent of single fathers and 42 percent of single mothers relied on SNAP. Taken together, these findings suggest that not only did SNAP receipt continue to rise in 2010, but it rose at an accelerated pace among households struggling the most, providing critical support to families in a tough economy.

\section{Policy Implications}

In a context of high poverty and unemployment, SNAP is one of the most responsive federal programs ${ }^{16}$ providing immediate benefits and helping millions of families to put food on the table. Despite its efficiency, however, SNAP is at risk for deep budget cuts. There is an effort to include SNAP cuts in the deficit reduction plan currently being developed by the Joint Select Committee on Deficit Reduction (that is, the "supercommittee"). On October 17, the Senate and House Agriculture committees recommended that the supercommittee reauthorize the Farm Bill with a $\$ 23$ billion reduction in funding. ${ }^{17}$ Because SNAP is included in the Farm Bill, this spending cut could include a significant portion of SNAP funding. While it is unclear how many families would experience a reduction in (or loss of) SNAP benefits under this plan, this brief makes it evident that the economy has not recovered enough to begin cutting SNAP funds. While budget cuts are imminent, legislators should carefully consider the effects on America's most vulnerable families when reducing funding for such important programs.

\section{Data}

This analysis is based on U.S. Census Bureau estimates from the 2007, 2009, and 2010 American Community Survey. For more details, please refer to the U.S. Census Bureau. ${ }^{18}$ Estimates here were produced by aggregating information from detailed tables available on American FactFinder. These estimates are meant to give perspective on SNAP use, but because they are based on survey data, one should use caution when comparing across categories, as the margins of error may place seemingly disparate estimates within reasonable sampling error. ${ }^{19}$ All differences highlighted in this brief are statistically significant $(p<0.05)$. 


\section{EN D N O T E S}

1. National Bureau of Economic Research, "U.S. Business Cycle Expansions and Contractions," Business Cycle Dating Committee (Washington, DC: National Bureau of Economic Research, 2010).

2. See Bureau of Labor Statistics, "The Employment Situation - September 2011," Economic News Release, October 7 (Washington, DC: Bureau of Labor Statistics, 2011) and Carmen DeNavas-Walt, Bernadette D. Proctor, and Jessica C. Smith, "Income, Poverty, and Health Insurance Coverage in the United States: 2010," Current Population Reports (Washington, DC: U.S. Census Bureau, 2011).

3. Food Research and Action Center, "Food Hardship in America - 2010," Food Hardship Report, March (Washington, DC: Food Research and Action Center, 2011).

4. Although not discussed in detail here, breakdowns by region are available in Table 1.

5. Food Research and Action Center, "SNAP/Food Stamp Monthly Participation Data” (Washington, DC: Food Research and Action Center, 2011).

6. Food Research and Action Center, "SNAP/Food Stamp Monthly Participation Data." Available at http://frac.org/ reports-and-resources/snapfood-stamp-monthly-participation-data/.

7. U.S. Census Bureau, “Table B22008: Median Household Income in the Past 12 Months (in 2010 Inflation-Adjusted Dollars) by Receipt of Food Stamps/SNAP in the Past 12 Months," American FactFinder (Washington, DC: U.S. Census Bureau, 2011).

8. Carsey Institute analysis of ACS data, available upon request. Note that income is a family-level estimate, compared with the household-level estimates used in the rest of the brief.

9. Food and Nutrition Service, "Supplemental Nutrition Assistance Program: Average Monthly Benefit Per Household" (Washington, DC: U.S. Department of Agriculture, 2011).

10. Here, food insecurity is measured with five questions designed to determine "whether households have enough food to eat and whether households are able to afford balanced meals" (see page 11 of citation). See Table 1 in Caroline Ratcliffe and Signe-Mary McKernan, "How Much Does SNAP Reduce Food Insecurity?” (Washington, DC: The Urban Institute, 2010).

11. In 2008, the USDA estimated that SNAP serves two-thirds of eligible people in the United States; these are the latest estimates available, though it is likely that participation has increased during the recession. See Karen E. Cunnyngham and Laura A. Castner, "Reaching Those in Need: State Supplemental Nutrition Assistance Program Participation Rates in 2008" (Washington, DC: U.S. Department of Agriculture, 2010).

12. Carsey Institute analysis of ACS data, available upon request.
13. Carsey Institute analysis of ACS data, available upon request. 14. Carsey Institute analysis of ACS data, available upon request. 15. Carsey Institute analysis of ACS data, available upon request. 16. Center on Budget and Policy Priorities, "Introduction to the Supplemental Nutrition Assistance Program (SNAP)," Policy Basics, March 21 (Washington, DC: Center on Budget and Policy Priorities, 2011).

17. U.S. Senate Committee on Agriculture, Nutrition, and Forestry, "Senate and House Agriculture Committees Offer Bipartisan, Bicameral Recommendation for Deficit Reduction to the Joint Committee," Ag Committee Newsroom, October 17 (Washington, DC: U.S. Senate Committee on Agriculture, Nutrition, and Forestry, 2011).

18. See U.S. Census Bureau's American Factfinder. Available at http://factfinder2.census.gov.

19. See U.S. Census Bureau's American Factfinder. Available at http://factfinder2.census.gov.

\section{ABOUT THE AUTHOR}

Jessica A. Bean is a vulnerable families research associate at the Carsey Institute (jessica.bean@unh.edu).

\section{A C K N O W L E D G E M E N T S}

The author would like to thank Ed Bolen at the Center on Budget and Policy Priorities and Bruce Mallory, Curt Grimm, Beth Mattingly, Amy Sterndale, and Laurel Lloyd Earnshaw at the Carsey Institute for their helpful comments and suggestions, as well as Donna Cooper at the Center for American Progress for assistance with reference materials. Special thanks to Jennifer Clayton at the Carsey Institute for providing analytical support. 


\section{$\triangle$ UNIVERSITY Ai. of NEW HAMPSHIRE}

\section{CARSEY}

Building knowledge for families and communities

The Carsey Institute conducts policy research on vulnerable children, youth, and families and on sustainable community development. We give policy makers and practitioners timely, independent resources to effect change in their communities.

This work was supported by the Annie E. Casey Foundation, the W. K. Kellogg Foundation, and an anonymous donor.

Huddleston Hall

73 Main Street

Durham, NH 03824

$(603) 862-2821$

www.carseyinstitute.unh.edu 